$\begin{array}{ll}\text { Variants } & \begin{array}{l}\text { Variants } \\ \text { The Journal of the European Society for Textual } \\ \text { Scholarship }\end{array}\end{array}$

15-16 | 2021

Textual Scholarship in the Twenty-First Century

\title{
Carlo Emilio Gadda, Quer pasticciaccio brutto de via Merulana
}

\section{Manuela Bertone}

\section{OpenEdition \\ Journals}

Electronic version

URL: https://journals.openedition.org/variants/1479

DOI: 10.4000/variants. 1479

ISSN: 1879-6095

\section{Publisher}

European Society for Textual Scholarship

\section{Printed version}

Date of publication: 1 July 2021

Number of pages: 261-264

ISSN: 1573-3084

\section{Electronic reference}

Manuela Bertone, "Carlo Emilio Gadda, Quer pasticciaccio brutto de via Merulana", Variants [Online],

15-16 | 2021, Online since 01 July 2021, connection on 16 July 2021. URL: http://

journals.openedition.org/variants/1479 ; DOl: https://doi.org/10.4000/variants.1479 
Review of Carlo Emilio Gadda, Quer pasticciaccio brutto de via Merulana. Ed. Giorgio Pinotti. Milano: Adelphi, 2018. 370 pp. ISBN: 978-8-84-593306-6.

Giorgio Pinotti, a refined connoisseur of Carlo Emilio Gadda, offers again in the new edition of the works of the Milanese writer, which Adelphi has been publishing for a few years, a text of Quer pasticciaccio brutto de via Merulana [That Awful Mess on Via Merulana] which is identical to the text which we are already familiar with, being based on the second reprint, revised and amended by the author, issued as a volume-publication in September 1957, soon after the first one, available from the end of July of that same year.

In the absence of textual variants suited to entice Pinotti's philological talent, he still gifts us a useful "Nota al testo" [Note on the Text] of approximately fifty pages, where he revisits the troubled composition of the novel, beginning with the 1945 Roman crime news that inspired Gadda to pen the novel, up until the present edition.

As Pinotti unravels the textual history for us (a sort of novel within the novel, one might say) in an impeccable chronological order, abounding in dramatic twists, he shares several novelties consisting in a few flashes from documents rich in sketches and working notes, recently unearthed among the Gadda papers preserved at the Archivio Liberati in Villafranca di Verona. Among the most significant, we recommend four photographs in the Ager Romanus by Gadda himself (1953), while he was exploring the Latian countryside in order to achieve a more mimetic representation of the territory. A curiously suggestive "finale 'imperfetto'" ["imperfect" ending] (Pinotti 2018, 322; quoting Gadda), handwritten on a squared sheet, is another find. It was most likely intended to seal a hypothetical second volume of the novel which, as we know, Gadda never authored, hence disappointing the expectations of his insistent and impatient publisher Livio Garzanti. A "splendido brano" [magnificent passage] of high lyrical tone, a single printed page long, whose reading we strongly recommend (Pinotti 2018, 323).

From the papers now resurfaced, attentively quoted but not exhibited by Pinotti, emerges the confirmation that Gadda strived to overcome structural concerns and imagine solutions regarding the ending not just of the never 
released second volume but of even that one, the only one, we are familiar with. However, Gadda's adumbrated hypotheses and his cherished solutions (honestly, not many) were, as a matter of fact, set aside and the Pasticciaccio, among short schemas and early drafts, pursuits of connections, completions and mends, ended up being left untouched as it is, with a conclusion that might seem provisional, but which Gadda decided, with unambiguous authority, to make definitive.

To tell the truth, upon examining the documentary fragments produced by Pinotti, we are rather confirmed in our belief that Gadda had no intention to send a sequel to press. Ready to make any pledge to his publishers as long as he could break free from their pressing demands and injunctions, the writer did not feel, like Garzanti, the necessity to repeat the commercial success of the novel. Pinotti, one of the few interpreters of the Pasticciaccio who, once again, believes that Gadda intended to end his crime fiction novel by revealing the culprit, as already argued in his annotated edition of the correspondence between Gadda and Pietro Citati (Gadda 2013), insists here that the auto-exegetic pronouncements which Gadda offered through the years, aiming to defend his choice not to close the book, are pretextuous. Pinotti, therefore, confirms that in his opinion the author's explanations should be construed as misleading statements, as attempts to ascribe, from the sixties onwards, a narrative défaillance "a un meditato disegno, trasformando così la resa in vittoria" [to a pondered design, in order to turn surrender into victory] (Pinotti 2018, 347). However, Pinotti later admits, with delightful acrobatics, that the authorial statements are justified by the fearless solution which Gadda devised for the ending, and recovers, surprisingly, a famous pronouncement by Giancarlo Roscioni - who, for that matter, was hardly flatteur towards a narrator of so travelled craftiness such as Gadda according to whom the unfinished nature of the work should be ascribed to the fatigue of the chess player who, "dopo aver cercato di prevedere il maggior numero possibile di mosse [...], sposti la prima pedina che lo liberi dal compito di ulteriormente riflettere e decidere" [having attempted to envisage the highest number of moves $[\ldots]$, opts for the first piece which can free him from the task of thinking and deciding any further] (Roscioni 1975, 91-92; see Pinotti 2018 347). But is it really likely that Gadda put so much effort retrospectively in fabricating and then disseminating nothing more than a captivating meta-textual tale in order to cover up a creative defeat and avoid the admission of guilt? As a matter of fact, the conveyor of the most plausible answer to this question is still Gianfranco Contini, who suggested taking authorial intention duly into account, observing the following:

Tutti sanno che il Pasticciaccio è, anche nell'ultima edizione, un libro incompiuto; ma, precisazione ben più importante, un libro, se non proprio così impostato intenzionalmente, accettato deliberatamente come incompiuto. Se la fine sia stata soltanto abbozzata o non abbia proceduto oltre la concezione mentale, è cosa del tutto secondaria di fronte a quest'accettazione, che Gadda difese (per la verità senza troppa fatica) contro le insistenze editoriali. 
[Everybody knows that the Pasticciaccio is, even in its last edition, an unfinished book; but, as it is far more important to clarify, a book which was, if not quite intentionally so configured, still deliberately accepted as unfinished. Whether the ending was only outlined or it never progressed beyond the mental conception, is definitely of secondary importance vis-àvis such acceptance, which Gadda defended (as a matter of fact without too much effort), against the insistence of his publisher.]

(Contini 1989. 45-46)

Ultimately, it is not surprising that the great scholar's assessment radically differs from that of great editors such as Citati (in the past) and Pinotti (nowadays): exactly like the great publishing houses which employ them, they ardently desire to unearth abundant unpublished materials to be sent to press, to the extent of always hoping that a manuscript perhaps vaguely promised one day materializes as a substantial rediscovered autograph. Contini instead assessed Gadda's discourse around the novel for what it is: perhaps just an act, but an authorial act, more assertive than evasive. And indeed, if one considers Gadda's statements about his novel, it definitely does not look like his thoughts on the conclusion of the Pasticciaccio tended towards the digression or the misdirection, nor even towards the pis-aller of the drained chess player. On the contrary, one might argue that Gadda attempted to rigorously support the reasons for an originality not suffered and far from casual. And in any case, Pinotti himself, for the sake of transparency, reminds us that since as early as 1958 Gadda wrote to his cousin Piero Gadda Conti that he did not wish to hear ever again of the Pasticciaccio, also acknowledging: "resterà dunque una chimera la continuazione-fine auspicata dall'editore" [the continuation-ending yearned for by the publisher will therefore remain a chimera] (Gadda Conti 1974. 161; see Pinotti 2018. 346).

It is not necessary to eulogize Gadda's Roman novel yet again, since it has already been widely reviewed through the decades and has been the object of numerous critical studies produced by specialists and mostly meant for them. To those who intend to approach this indispensable classic of European literature for the first time - a work which has come back to the fore precisely due to Adelphi's well-timed new edition, but which remains arduously decipherable for the reader not accustomed to Gadda's extremely difficult prose - it may be suggested to draw on tools which, together with the already quoted "Nota al testo", can further the understanding of the novel. In the first instance the sturdy and valuable Commento [Commentary] of the Pasticciaccio, an impressive work (2 vols., 1184 pp.) coordinated by Maria Antonietta Terzoli (2015), which eviscerates the text line by line, with glosses of various length and intensity: a useful encyclopaedia that may be consulted to escape doubts and uncertainties, but also, if one wishes to go further in-depth, in order to discover extraordinary layerings of meaning not immediately perceptible. Whoever wishes to tackle the novel using more manageable aids will instead have the chance to draw on two additional volumes, prepared again by Terzoli together with the pupils attending her Romanisches Seminar at the University of Basel: to the first one, Un 
meraviglioso ordegno. Paradigmi e modelli nel Pasticciaccio di Gadda [A Marvelous Device: Paradigms and Models in Gadda's Pasticciaccio] (2013), is entrusted a broad and new critical analysis, involving multiple voices, which preludes to the publication of the Commento; the second one, Gadda: guida al Pasticciaccio [Gadda: A Guide to the Pasticciaccio] (2016), suggests a first approach to the novel, offering a chapter-by-chapter reading which allows even the most inexperienced to find their way through the maze-like plot and the equally maze-like nooks and crannies of the Latian countryside and of the tenement in Via Merulana where the narrative yarn tangles into an awful mess.

\section{Bibliography}

Contini, Gianfranco, 1989. Quarant'anni d'amicizia. Scritti su Carlo Emilio Gadda (1934-1988). Torino: Einaudi.

Gadda, Carlo Emilio, 2013. Un gomitolo di concause. Lettere a Pietro Citati (1957-1969), edited by Giorgio Pinotti. Milano: Adelphi.

Gadda Conti, Piero, 1974. Le Confessioni di Carlo Emilio Gadda. Milano: Pan.

PinotTi, Giongio, 2018. "Nota al testo." In Quer pasticciaccio brutto de via Merulana, authored by Gadda, Carlo Emilio, edited by Giorgio Pinotti, Milano: Adelphi, pages 309-55.

Roscioni, Gian Carlo, 1975. La disarmonia prestabilita. Studio su Gadda. Torino: Einaudi.

Terzoli, Maria Antonietta, ed., 2015. Commento a Quer pasticciaccio brutto de via Merulana di Carlo Emilio Gadda. Roma: Carocci.

_ 2016. Gadda: guida al "Pasticciaccio". Roma: Carocci.

Terzoli, Maria Antonietta, Cosetta Veronese, and Vincenzo Vitale, eds., 2013. Un meraviglioso ordegno. Paradigmi e modelli nel "Pasticciaccio" di Gadda. Roma: Carocci. 